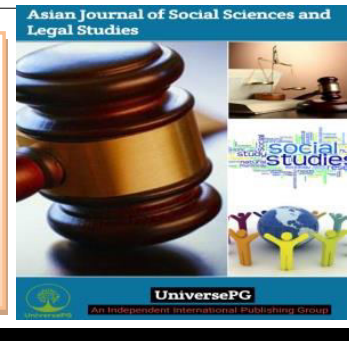

\title{
Sketch of the Copyright Act, 2000 in Bangladesh: Enforcement, Impediments and Solutions
}

\author{
Shahidul Alam ${ }^{1}$, Md. Al-Amin ${ }^{1}$, and Sharifa Yasmin Mukta ${ }^{2}$ \\ ${ }^{1}$ Department of Law, Gono Bishwabidyalay, Savar, Dhaka-1344, Bangladesh, and ${ }^{2}$ Department of Law, Bangabandhu \\ Sheikh Mujibur Rahman Science and Technology University, Gopalganj-8100, Bangladesh.
}

*Correspondence: mr.rana59@gmail.com (Shahidul Alam, Lecturer, Department of Law, Gono Bishwabidyalay, Dhaka, Bangladesh).

\begin{abstract}
In the Modern era, the concept of intellectual property is a matter of significance, and copyright (CR) is a great part of it. Copyright provides the author and the creator of the original works a negative right on literature, dramatics, musical art, cinematograph, and sound recording. By virtue of modern technology among intellectual property, CR is getting more important. Though there is The Copyright Act, 2000 (CA) in Bangladesh is going to be difficult to protect copyright for some defect in the act and the lack of necessary scheme and mechanisms of the government. It is proper time to protect the authors and the creators of copyright by preventing the infringement of copyright through various measures of the state. To protect copyright state should take steps to implement The Copyright Act, 2000 (CA) and it is needed to make some necessary amendments in the present act. Through this research, the researcher tries to highlight current copyright status of Bangladesh, an overview of The Copyright Act, 2000 (CA), impediments and solutions to remove the impediments.
\end{abstract}

Keywords: Copyright, Intellectual property, Sound recording, Assignment, Infringement, and Remedies.

\section{INTRODUCTION:}

Copyright, the important part of intellectual property right is assuming an increasing role and importance in international trade, in investment, in economic relations and in socio-economic and cultural growth. Copyright, deals with creations of the human intellect (Gaurav Mehrotha, 2002), which is a powerful stimulus for intellectual creativity ${ }^{1}$. Copy-right is a legal concept which is created by the statute. Copyright is a negative right which prevents physical material from being copied existing in the area of arts and literature. Copyright does not exist in ideas (Debroy, Bibek, 1998) $)^{2}$. The CA provides protecttion for the works literary, dramatic, musical and artistic which are original in nature and also for cinematograph films and sound recording (Modak, $2008)^{3}$. Copyright gives the author of the work to be credited and to determine who may modify the work UniversePG I www.universepg.com to other forms, who may perform the work, who may be financially benefited from it and other related mono-poly rights (Super Cassette Industries Ltd, $2008)^{4}$.The state should endeavour to create such a platform in which intellectual and physical labour in each form, shall become a complete evolution of creative effort and also of the human personality (Gopal Das, 1938) ${ }^{5}$. The aim of this law is to give the creator of original work a monopolistic right in their deeds for certain hour of time and facilitate them to earn financial profit and reputation.

\section{Objectives of the Copyright Law}

The motive of this law is to save the proprietor of the work from an unlawful reproduction or exploitation of his work by others (Hosen, 2017) ${ }^{6}$. CR law encourages authors, composers and artists to create original work by awarding them with monopolistic 
right for specific period. They can earn financial benefits by reproducing the works for publishing and selling them to public. The first work is protected from being unlawfully reproduced or exploited by unauthorized persons (Mohammad, 2013) ${ }^{7}$. Copyright provides the owners, for their original works, universal recognition. When any person creates something at first instance with his efficiency and labour, it generally associates to him and the others are prevented to make any financial gain out of the efficiency and labour the first author without his consent (Monirul Azam, 2008) ${ }^{8}$. Copyright provides the owner a monopolistic right by which he is entitled to prevent third parties from doing that which the owner is solely allowed to do under the Act (Narayanan, 2017) ${ }^{9}$.

\section{Sketch of the Copyright Act, 2000}

\subsection{Copyright}

Copyright primarily means right of multiplying copies of main work by the person who creates a work at the first instance. As a natural consequence, it excludes unauthorized person from multiplying copies (Shringar cinemas Ltd, 2008) ${ }^{10}$. Copyright is originated by the statute and by no other ways. No person is claimant to copyright or any similar right in any creative work except those given by this Act. Mere ideas or thoughts are not safeguarded by copyright. Only when the ideas are expressed in any real form of works it is covered with preservation of the copyright. Mere taking of the ideas of any other person is not called infringement of copyright (Singh, 2013) $)^{11}$. Copyright is a monopolistic right of the creator of work who has the authority to stop other persons from taking advantage of the work without his will. It creates a check and balance between the claim and power of the proprietor and that of the public in preserving the public domain, or claiming the copyright and giving protect it by the copyright law (The Constitution of Bangladesh, 1972) $)^{12}$. Section 15 of the CA define copyright like -

In accordance with the act, copyright means the monopolistic right, doing any of the deeds mentioned below in contact to a work or any substantial part of it namely;

a) Original literary, dramatic, musical and artistic works;

b) Cinematograph films; and

c) Sound recording
3.1.1 Literary Works: Literary works expressed in printing or writing irrespective of the question whether the excellence of style is high (The Copyright Act, 2000) ${ }^{13}$ Literary works includes works on humanity, religious, social scientific and any other written book, composed, translated, converted, adapted, creative, research, factual and shall also include computer programmes, tables and creative compilations including computer databases (Time Warner Entertainment Co. L.P, 2007) $)^{14}$. In Celador Productions Ltd v Gaurav Mehrotha (Walter v. Lane, 1900) ${ }^{15}$ a form of telephone quiz programme called Kaun Banega Crorepatiwas hijacked by the defendant. When the logos, names and identical photographs of the plaintiff and of the respondent deceptively resemble to that of the respondent the court grants and decree of injunction.

3.1.2 Dramatic Work: Dramatic works includes any piece for recitation, choreographic work or entertainment in dumb show, the scenic arrangement or acting from which is fixed in writing or otherwise but excludes a cinematograph film ${ }^{16}$. Although cinematography film is not a dramatic work, the script thereof is a dramatic work ${ }^{17}$.

3.1.3 Musical Works: Musical work means a work consisting of music and includes any graphical idea of such work but excludes words or any deed designed for singing, delivered or played with the music ${ }^{18}$. In Edmond v. Stern,${ }^{19}$ It was decided that for the safeguard of work of music to be safeguarded, it ought to be original and novel but an adaptation may have copyright protection.

\subsubsection{Artistic works: Artistic works means:}

a) a painting, sculpture, a drawing of any description and also include a diagram, map, chart or plan, work possesses artistic quality in regarding to an engraving, a photograph;

b) any kind of architectural deed; and

c) artistic craftsmanship work of any form ${ }^{20}$.

d) reconstruction of the deed in other real form encircling stocking of it in any method by electronic or several means, depiction in three dimensions of a two-dimensional work or in two dimensions of a three-dimensional work.

e) to use by conveying or letting on hire any artistic deed for commercial purpose or communicating it to mass people;

f) issuing copies to mass people; 
g) to include the deed in each cinematograph film;

h) to make any adjustment;

i) doing things specified above in connection to an adjustment ${ }^{21}$.

3.1.5 Cinematograph Film: Generally, cinematograph means any work created by any instrumental procedure or by radio-diffusion. It also includes imitation of film, together with a photograph of any picture of storing part of it; or reserving of it in any way by electronic or various means.

3.1.6 Sound Recording: Sound recording is a recording of sound by any medium and from which that sounds is capable of being produced by any method. ${ }^{22}$ It also means creating any other kind of sound recording and let it be used by selling or letting on hire any imitation of the sound recording, or communicating the sound recording to mass people, etc. ${ }^{4}$

\subsection{Copyright (CR) Registration}

In Bangladesh registration of CR is not mandatory it depends on the will of the creators or authors. It is not condition precedent for acquiring proprietorship of CR to original creation. ${ }^{23}$ In a case Walter v. Lane, the House of Lords had decided that, for securing $\mathrm{CR}$ protection to a deed registration of the deed is not mandatory. According to section 56 of The CA the steps of CR registration is-

a) The author, publisher, owner or other person interested in the CR of any deed may make apply in the prearranged form along with the fixed fees to registrar for entering essentials of the deed in register of $\mathrm{CR}$.

b) After receiving the application regarding any deed regarding sub-section (1), the registrar can, after such investigation as he can deem fit, write the essentials of the deed in register of $\mathrm{CR}$ and issue a certificate of such registration to the claimant unless, for causes to be recorded in writing, he considers that such entry ought not to be made regarding any deed.

\subsection{Duration of Copyright (CR) Protection}

Copyright of the creator does not continue for indefinite time. The law secures copyright for a certain phase of time during which the rights of the proprietor exist and the proprietor can exclusively enjoy the right during that time. The time is calculated from the day of creation of the deed. CR protection is given not only over the lifetime of the person behind or creator but also for some specific phase of time after his death. It ensures the author or creator financial benefits and also for their legal heirs. The investment cost made by the persons behind or the creators for the manufacture and the spreading of their deeds are safeguarded by the CR protection

In those states who are the member of the Berne Convention, as well as in many other countries except the member of Berne convention, the length of copyright provided for by national law is the life of the creator and not less than fifty Yrs after the death of the author. In current Yrs, a trend has emerged regarding lengthening the tenure of $\mathrm{CR}$ protection ${ }^{4}$. Length of the copyright (CR) in different forms of work has been discussed in chapter v-vi of The CA that has been stated concisely below:

1. the term for literary, artistic, musical, dramatic works is life of the creator and 60 years (Yrs) from the demise of the creator which shall be computed from the opening of the calendar years (CY) after his demise ${ }^{24}$

2. the term for photograph is 60 Yrs from the publication year (PY) which shall be computed from the opening of the $\mathrm{CY}$ after the publication; ${ }^{25}$

3. the term for cinematograph film is 60 Yrs from the PY which shall be computed from the opening of the $\mathrm{CY}$ after the publication; ${ }^{26}$

4. the term for sound recording is 60 Yrs from the PY which shall be computed from the opening of the $\mathrm{CY}$ after the publication; ${ }^{27}$

5. the term for computer programme is $60 \mathrm{Yrs}$ from the PY which shall be computed from the opening of the $\mathrm{CY}$ after the publication; ${ }^{28}$

6. the term for Government works is 60 Yrs from the PY which shall be computed from the opening of the $\mathrm{CY}$ after the publication; ${ }^{29}$

7. the term for the work of local authority is 60 Yrs from the PY which shall be computed from the opening of the CY after the publiccation; ${ }^{30}$

8. the term for the works of international organization is 60 Yrs from the PY which shall be computed from the opening of the $\mathrm{CY}$ after the publication; ${ }^{31}$

9. the term for broadcasting reproduction is 25 Yrs from the day when it is broadcast which 
shall be computed from the opening of the CY after the broadcasting is made; ${ }^{32}$

10. the term for performance 50 Yrs from the day when it is performed which shall be computed from the opening of the $\mathrm{CY}$ after the performance is showed ${ }^{33}$

11. the term for published edition (typographical arrangement) is 25 Yrs from the PY which shall be computed from the opening of the CY after the publication; ${ }^{34}$

12. the term for combined ownership of a deed is 60 Yrs which shall be computed from the demise of last surviving author. ${ }^{35}$

\subsection{Transfer of Copyright}

3.4.1 Assignment: An assignment (Assnmnt) is in sprit a transfer of ownership even it is partial. It is voluntary change of proprietorship of the deed. Basically, copyright may be assigned to any third party under certain restrictions of the CA. ${ }^{4}$ The owner or author may make the Assnmnt of CR in an present deed or in a upcoming deed either to the full of his right otherwise to any piece of it with or without limitation and also for any shorter period or for the full period of the copyright. Assnmnt of CR in any upcoming deed shall not be effective until the deed comes into reality. After the creation of Assnmnt the assignee is entitled to that rights included in CR which have been transferred to him and the remaining rights included in CR belongs to the assignor. $\mathrm{He}$ is treated as proprietor of such remainning right by the $\mathrm{CA}$ and the rules of this $\mathrm{CA}$ shall have consequence accordingly. ${ }^{36}$

Conditions need to be fulfilled for making an Assnmnt as follows:

- Assnmnt of the CR in any deed shall be written and signed by duly authorized agent or by the assignor;

- The transfer of CR in any deed shall mention such terms as needed to recognize such deed, indicate the rights, length and territorial coverage of such transfer;

- The Assnmnt of CR in any deed shall define the sum and currency of payment;

- Weather the parties have fixed any method and ground of correction, addition or extinction of Assnmnt shall be covered in the Assnmnt;
- Non use of the right of the transferee end of 1 year from the day of Assnmnt shall be regarded the vanish of the right transferred to him except the Assnmnt directs otherwise;

- The Assnmnt is valid for 5 Yrs from the day of the Assnmnt but for the term mentioned in the deed of Assnmnt;

- The territorial limit of Assnmnt shall extend to whole of Bangladesh unless limited to any territory by the deed. ${ }^{37}$

3.4.2 License: The CR owner may transfer any of the interest in the CR granting through license to others in his existing and future works. The license deed shall be signed by duly authorized agent or the proprietor. On condition that a license relating to $\mathrm{CR}$ in any present work shall be effective immediately and a license relating to $\mathrm{CR}$ in any upcoming work does not take effect as such it takes effect after the subsistence of the work. ${ }^{38}$

Explanation: The right of a man to whom license in any upcoming work is approved shall not be terminated on the demise of that man. After his demise the right is vested to his successors unless there are any specific terms in the deed of license. ${ }^{39}$ The Board acting as a statutory authority can exercise its powers now and then because a compulsory license can be granted not merely to one person but to more persons. ${ }^{40}$

\subsection{Infringement of Copyright}

The CR owner has negative right of exclusive nature to do certain act regarding the deed and to refraining others from doing unauthorized acts. The rights of creator of $\mathrm{CR}$ are infringed when any activities requiring approval of the creator is done by someone else without his or its consent ${ }^{41}$. Copyright infringement occurs in the below mentioned circumstances:

a) When any one, not having a license approved by the proprietor of the $\mathrm{CR}$ or the registering officer of copyrights according to the provision of the $\mathrm{CA}$ or in violation of the conditions of a license so approved or any condition imposed by the proper authority according to the CA-

- does something, the monopolistic right to perform which is according to the CA vested upon the proprietor of the $\mathrm{CR}$; or

- give permission for gain any area being used for representation of the deed to the 
mass people where such representation creates an breach of the CR in the deed unless he had absence of awareness and had no proper argument to believe that such representation likely an contravention of $\mathrm{CR}$; or

(b) When any one-

- sales or hires, abets in selling or hiring, or displays and offers for selling or hiring, or

- allotting the copies for business purpose in such a way or to an degree that affects the owner prejudicially, or

- exhibition in public for business purpose, or

- importation of forged copies of deed into Bangladesh.

For the purposes of this section, the imitation of a literary, dramatic, musical or artistic deed in the form of a cinematograph film is regarded to be an infringing copy. ${ }^{42}$ In Gopal Das v. Jagannath prasad, ${ }^{43}$ the court held that nobody is entitle to avail himself of the previous labour of another for conveying to the mass people the same information, although he may append additional information to that already published ${ }^{44}$.

3.5.1 Essential ingredients of infringement: When someone does any of the acts stated below without the authorization of CR owner it turns into contravention of $\mathrm{CR}$ :

(a) imitation of the deed of any substantive form;

(b) publication of deed;

(c) contact of the deed to the general people;

(d) performance of the deed to the general people and

(e) making adaption in and translations of the deed and doing any acts stated above regarding substantial component of the deed. ${ }^{45}$

\subsubsection{Acts that do not amount to infringement:}

The facts stated below do not create contravention of a CR:

1. private or individual use together with research;

2. criticizing or reviewing of the deed or other deeds;

3. reporting recent cases and contemporary affairs with the reporting of dialogue adderssed in public. ${ }^{46}$

\subsection{Remedies}

3.6.1 Civil Remedies: The court gives civil remedies for the contravention of CR by injunction, compensation, financial records and otherwise. According to the Act remedies are given to the property owner of CR by the ways mentioned above unless there is any other exception in the CA. The remedies are given only when any provision of the $\mathrm{CA}$ is violated. When the defendant shows that during the contravention of copyright he did not know that copyright existed in the deed and he had proper reason to trust that $\mathrm{CR}$ did not exist in the deed then the court shall not grant any other remedies except injunction as to the contravention of $\mathrm{CR}$ and order for the profit which has been earned by the opposite party through utilizing the forged copies which is reasonable according to the circumstances.

Where, as to dramatic, musical and artistic work, a name appears on the published copies of the deed regarded to be the name of the author or the publisher, which one is applicable. As to artistic deed the name appeared on the deed during the making of it shall be regarded the name of the appropriate person. The expenses of the case are paid by which party it is decided in the discretion of the court. ${ }^{47}$.

3.6.1.1 Injunction: An injunction was granted where the licenses, without permission of licensor authorized third parties to take advance of the deed. Besides being an infringement, it was breach of the contractual obligation. ${ }^{48}$

3.6.2 Criminal remedies: The persons, who violate the requirements of the $\mathrm{CA}$, have to face the punishments which are provided by chapter 15 of The CA. Subject to section 66 of the CA all offences under the CA shall be cognizable by the Court of Session. Punishments which are imposed by different sections under the $\mathrm{CA}$ are stated below:

* Person guilty of infringement and abetment of infringement shall be punished with imprisonment upto 4 Yrs but not fewer than 6 months and also with fine that may extent to taka 2 lakh but shall not lower than taka 50 thousand; If the infringement is not for gain in course of business or trade court may impose punishment of imprisonment less than 6 months and fine less than 50 thousand taka. $^{49}$ 
* As to contravention of cinematograph film the punishment shall be imprisonment up to 5 Yrs but not lower than 1 year and also with fine up to 5 lakh but not lower than 1 lakh. ${ }^{50}$

* The convicted person for the second and every later offence shall be punished with sentence up to 3 Yrs however not lower than 1 year and also with fine up to 3lakh taka but not lower than 1 lakh taka. If the offence is not for gain then the punishment shall be imprisonment lower than 1 year and also fine lower than 1 lakh taka. ${ }^{51}$

* In case of infringement of computer programme the punishment shall be imprisonment up to 4 Yrs but shall not lower than 6 months or fine extent to 4 lakh taka but shall not lower than 1 lakh taka. ${ }^{52}$

* For using infringed computer programme the punishment shall be imprisonment up to 3 Yrs but shall not lower than 6 Months or fine extent to 3 lakh taka but shall not lower than 1 lakh taka. ${ }^{53}$

* The punishment for the person who poss-esses the plates for making infringed copies is imprisonment extent to 2 Yrs or fine extent to 50 thousand taka or with both. ${ }^{54}$

* The punishment for the person who makes any false entries in the book of register is imprisonment up to 2 Yrs or fine up to 10 thousand taka or with both. ${ }^{55}$

* The one who makes false statement intended to deceive or create influence any authority shall be convicted with sentenced extent to 2 Yrs or fine extent to 25 thousand taka or with both. $^{56}$

* The punishment for making false attribution of authority is detention extent to 2 Yrs or fine extent to 25 thousand taka or with both. ${ }^{57}$

3.6.3 Administrative Remedies: When any one is aggrieved for importation of any confiscated copies from foreign countries to Bangladesh may submit an application to the Registrar to ban the import of forged copies in Bangladesh. Then the registrar shall take step to ban the importation of forged copies and delivered the seized confiscated copies to the owner of the work. ${ }^{4}$

\section{Copyright Laws}

\subsection{Domestic Laws:}

- The Copyright Act, 2000

UniversePG I www.universepg.com
- The Copyright Rules, 2006

\subsection{International Laws:}

- Universal Copyright Convention at Geneva in 1952.

- Universal Copyright Convention as revised at Paris on $24^{\text {th }}$ July 1971.

- Berne Convention for the Protection of Literary and Artistic Works 1886, Paris Act of $24^{\text {th }}$ July 1971 as amended on September $28^{\text {th }}$ 1979.

- WIPO, World Intellectual Property Organization Diplomatic Conference Geneva, December 2 to 20, 1996 WIPO Copyright Treaty of December $20^{\text {th }} 1996$.

- WIPO, Performances and Phonograms Treaty of December $20^{\text {th }} 1996$.

- The World Trade Organization Agreement on Trade Related Aspects of Intellectual Property Rights, Final Act Marrakech on $15^{\text {th }}$ April $1994^{58}$.

\section{Reasons for Hardly Enforcement of Copyright Act, 2000 in Bangladesh:}

$>$ The people have a lack of awareness about copyright infringement because they have no clear idea of copyright. They are randomly infringing $\mathrm{CA}$ by their daily activities.

$>$ Copyright is protected for a finite session of time not endlessly.

$>$ Insufficient supplies for the safeguard of digital copyright. After the amendment in 2005 of The CA and The Copyright Rules, 2006 provides for the safeguard of computer software but still in sufficient.

$>$ There is a provision for the institution of copyright society in the CA but not a single society has been established yet.

$>$ There is lack of expert person in police plus custom officers regarding copyright so they can't perform their duties properly.

$>$ The police hardly hold suo-moto riad.

$>$ The adjudication of a case goes through a complex procedure. More fees for the advocates, lack of expert officers in the judgeship and the advocates, long time for the disposal of case make the procedure more complex.

$>$ There is no separate court for the disposal of copyright disputes. The cases are adjudicated by the ordinary courts. 
The CA and The Mobile Court Act, 2009 provides no provision for the conduction of mobile court for infringement of CR.

$>$ Nobody except the owner and the creator can reproduce, display or perform the protected deed for any purpose but some authors or owners want their works to be disseminated broadly and quickly. They prefer to obtain public attention rather than financial gain. This is a disadvantage.

\section{CONCLUSION:}

In Bangladesh, Article $20^{59}$ recognizes the intellectual property namely the $\mathrm{CR}$ and there is the $\mathrm{CA}$ as amended in 2005 and The CR Rules, 2006 to safeguard the deeds of the inventors and actual authors from piracy. In Bangladesh copyright is infringing randomly in addition to she is listed on the top among countries in the world in violating copy-right. At present infringement through online platform is concerning along with traditional form of infringement. It is harmful for the creator, author plus for the state as a whole in communal, monetary and artistic development. The goal of the CA is to allow the creator and the author financially benefited and reputed worldwide by their works and to punish them who are involved in breach of CR. But we fail to stop infringement of CR due to absence of consciousness and proper use of CR. It is needed to create the citizens aware of $\mathrm{CR}$ by workshop, seminar and symposium. If citizens understand the copyright protection properly it will be helpful for the country through communal, monetary and artistic development and the authors through financial gain and reputation. Proper use of the CR laws in alliance with the digital security law and cyber law will help us to create the country acquainted with the civilized world as innovative country.

\section{Recommendations:}

$>$ Making people aware of copyright through workshop, seminar and symposiums.

$>$ Establishing copyright society which will act against the $\mathrm{CR}$ infringement and facilitate the proper marketing of the deeds protected by CR law.

$>$ Introducing the idea of $\mathrm{CR}$ in course curriculum at undergraduate level.

$>$ Establishing special cell in the custom and the police force by expert officers.
$>$ Conducting police raid on receiving information and complaint.

$>$ Taking actions against the law breakers who are engaged in piracy by reproducing, selling, buying, marketing and in new way.

$>$ Establishing specialized separate copyright court as a minimum one court in each division and arranging training for the judges and enriching them with expertise.

$>$ Removing complexity in the adjudication of cases by speedy trial and by providing the court with modern equipment.

> Making proper remedies available on easy process and increasing the sum of fine and easy payment to the proper Claimant.

$>$ Associating the digital Security laws and the cyber laws with the CA.

\section{ACKNOWLEDGEMANT:}

Many thanks to the co-researchers for their cordial support in completion of this research and special thanks to Sharifa Yasmin Mukta Smy beloved wife and co-researcher for encouraging me to make this research successful.

\section{CONFLICTS OF INTEREST:}

The authors declared that they have no potential or competing conflicts of interest with respect of the research work.

\section{REFERENCES:}

1) Celador Productions Ltd $v$ Gaurav Mehrotha, (2002). 96 DLT 543: (2003) 26 PTC 140.

https://indiankanoon.org/doc/1840648/

2) Debroy, Bibek, (1998). Intellectual Property Rights, Delhi-110052, B.R. Publishing Corporation.

3) Eastern Book Co. v D.B. Modak, (2008). 1 SCC 1: AIR 2008 SC 809.

https://indiankanoon.org/doc/1062099/

4) Entertainment Network (India) Ltd v Super Cassette Industries Ltd, (2008). 13 SSC 30.

5) Gopal Das v. Jagannath prasad AIR 1938 All 266.

https://indiankanoon.org/doc/426845/

6) Hosen, M. F. (2017). An Overview of the Copyright Protection Laws in Bangladesh-A Critical Analysis of the Copyright Act, 2000 with Its Loopholes and Recommendations. Beijing Law Review, 8, 191-211. https://doi.org/10.4236/blr.2017.82011 
7) Mohammad, N. (June, 2013). Intellectual Property Law in Bangladesh. Dhaka-1205: Five Jewel Publication.

8) Monirul Azam, (2008). Intellectual property WTO and Bangladesh, New Warsi Book Corporation, Dhaka, Pp. 188-213.

9) Narayanan P. (2017). Intellectual Property Law ( $3^{\text {rd }}$ Edition, Revised), Kolkata: Eastern Law House Pvt. Ltd. https://www.flipkart.com/eastern-law-house-sintellectual-property-p-narayanan/p/itmfffdygbaybgae

10) Shringar cinemas Ltd $v$ Bharat Bala productions (p) Ltd, (2008). 3 MahLj 564. https://indiankanoon.org/doc/588596/

11) Singh, A. (2013). Intellectual Property Law. Lucknow: Eastern Book Company.
12) The Constitution of Bangladesh, 1972. http://bdlaws.minlaw.gov.bd/act-367.html

13) The Copyright Act 2000 (Act no xxviii). https://www.wipo.int/edocs/lexdocs/laws/en/ie lie098en.pdf

14) Time Warner Entertainment Co. L.P v. RPG Netcom: AIR, (2007). Del 226: (2007) AIHC 542 NOC: 2007 (6) ALJ (NOC) 1014 DLT 758: 2007 (34) PTC 668. https://indiankanoon.org/doc/1571600/

15) Walter v. Lane, 1900 AC 539: (1900-03) ALL ER Rep Ext 1666 (HL). https://www.coursehero.com/file/27735964/W alter-v-Lanepdf/

\section{ENDNOTES:}

${ }^{1}$ Debroy. Bibek (1998) Intellectual Property Rights, Delhi-110052, B.R. Publishing Corporation, P. 124

${ }^{2}$ P. Narayanan (2017) Intellectual Property Law ( $3^{\text {rd }}$ Edition, Revised), Kolkata: Eastern Law House Pvt. Ltd., P. 255

${ }^{3}$ Section 15, The Copyright Act 2000 (the CA).

${ }^{4}$ Hosen, M. F. (2017). An Overview of the Copyright Protection Laws in Bangladesh-A Critical Analysis of the Copyright Act, 2000 with Its Loopholes and Recommendations. Beijing Law Review, 8, 191-211.

${ }_{5}^{5}$ Article 20, The Constitution of Bangladesh 1972.

${ }^{6}$ Eastern Book Co. v D.B. Modak, (2008) 1 SCC 1: AIR 2008 SC 809

${ }^{7}$ Mohammad, N. (June, 2013). Intellectual Property Law in Bangladesh. Dhaka-1205: Five Jewel Publication. P.41

${ }^{8}$ Singh, A. (2013). Intellectual Property Law. Lucknow: Eastern Book Company, P. 145

${ }^{9}$ Time Warner Entertainment Co. L.P v. RPG Netcom: AIR 2007 Del 226: 2007 AIHC 542 NOC: 2007 (6) ALJ (NOC) 1014 DLT 758: 2007 (34) PTC 668

${ }^{10}$ Walter v. Lane, 1900 AC 539: (1900-03) ALL ER Rep Ext 1666 (HL)

${ }^{11}$ P. Narayanan (2017) Intellectual Property Law $\left(3^{\text {rd }}\right.$ Edition, Revised), Kolkata: Eastern Law House Pvt. Ltd., P. 255

${ }^{12}$ Singh, A. (2013). Intellectual Property Law. Lucknow: Eastern Book Company, P. 166

${ }^{13}$ P. Narayanan (1997) Intellectual Property Law, (2 ${ }^{\text {nd }}$ Edition) Eastern Law House Pvt. Ltd., P. 223

${ }^{14}$ Section 2 (46), The CA

${ }^{15}$ (2002) 96 DLT 543:(2003) 26 PTC 140

${ }^{16}$ Section 2 (18), The CA

${ }^{17}$ P. Narayanan (2017) Intellectual Property Law $\left(3^{\text {rd }}\right.$ Edition, Revised), Kolkata: Eastern Law House Pvt. Ltd., P. 263

${ }^{18}$ Section 2 (37), The CA

${ }^{19} 1918,879$

${ }^{20}$ Section 2 (36), The CA

${ }^{21}$ Singh, A. (2013). Intellectual Property Law. Lucknow: Eastern Book Company, P.167

${ }^{22}$ Mohammad, N. (June, 2013). Intellectual Property Law in Bangladesh. Dhaka-1205: Five Jewel

Publication. P.49

${ }^{23} \mathrm{Ibid}$, P.79

${ }^{24}$ Section 24, The CA

${ }^{25}$ Section 28, Ibid

${ }^{26}$ Section 26, Ibid

${ }^{27}$ Section 27, Ibid

${ }^{28}$ Section 28 A, Ibid

${ }^{29}$ Section 30, Ibid

${ }^{30}$ Section 31, Ibid 


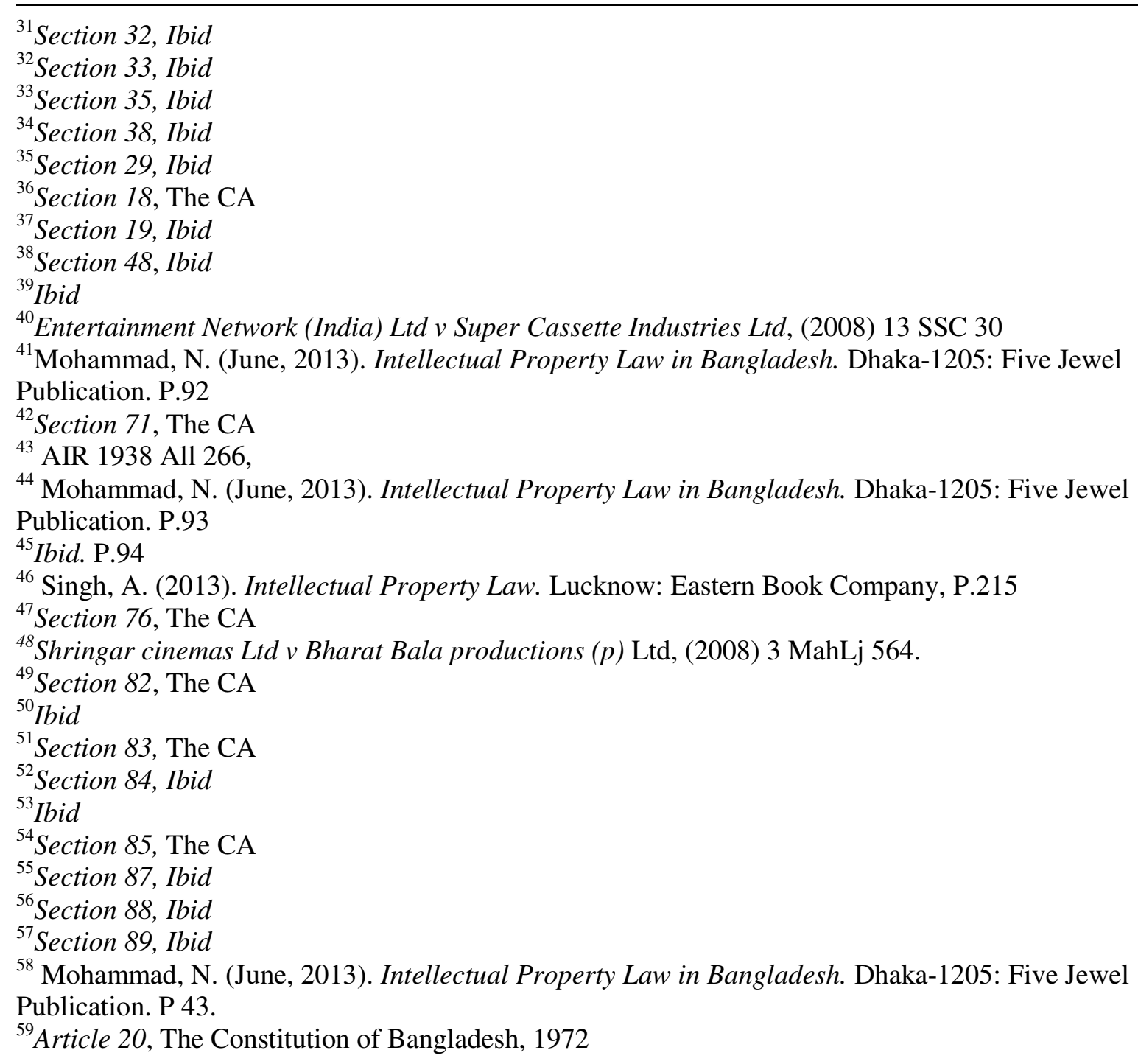

Citation: Alam S, Al-Amin M, and Mukta SY. (2020). Sketch of the copyright act, 2000 in Bangladesh: enforcement, impediments and solutions, Asian J. Soc. Sci. Leg. Stud., 2(6), 129-137. 